\title{
Investigation of Labor Remuneration Offenses
}

\author{
Elena Nikolaevna Sochneva \\ Economics Chair, Siberian Federal \\ University \\ Krasnoyarsk, Russia
}

\author{
Anna Andreevna Malakhova \\ Economics Chair, Siberian Federal \\ University \\ Krasnoyarsk, Russia
}

\author{
Irina Igorevna Zyryanova \\ Economics Chair, Siberian Federal \\ University \\ Krasnoyarsk, Russia \\ z.i.irina@mail.ru
}

\begin{abstract}
In this paper various current criminal schemes that lead to nonpayment of wages and to understating payments to social funds are revealed. The methodology of judicial economic expertise is discussed. It is proved that the economic crime investigation should be based on the criminological component, which, in its turn, in terms of economic crimes depends on the influence of many factors, including the external environment. In Russia, the informal labor market is steadily growing, which makes it necessary to prove the fact of labor relations itself, and on its basis, non-payment of wages. It is necessary to secure at the level of the Constitution a ban on informal work. It is also advisable to introduce criminal liability for the use of informal labor. All crimes in the sphere of remuneration are divided into four groups, each of which implies its own specific forensic investigation methods. While conducting judicial economic expertise in investigating labor remuneration crimes, it is advisable not only to rely on the seizure and analysis of accounting documents, but also to examine carefully all the elements of social and labor relations at the level of an enterprise. It is also necessary to analyze the activities of a company as a whole in order to understand the causes and to find out the scheme of the crime while investigating any economic crimes.
\end{abstract}

\section{CCS CONCEPTS}

- Applied computing $\rightarrow$ Law, social and behavioral sciences $\rightarrow$ Economics - Social and professional topics $\rightarrow$ Professional topics $\rightarrow$ Economic impact

\section{ACM Reference format:}

Elena Nikolaevna Sochneva, Anna Andreevna Malakhova, Irina Igorevna Zyryanova. 2020. Investigation of Labor Remuneration Offenses. In Proceedings of ACM III International Scientific and Practical Conference (DEFIN2020), March 19-20, 2020, St.Petersburg, Russian Federation, 5 pages. https://doi.org/10.1145/3388984.3390624

\section{Introduction}

The right to labor remuneration is guaranteed by the Constitution of the Russian Federation [1], and in accordance with Art. 22 of the Labor Code of the Russian Federation the employer is obliged to pay the full due wages within the time limits established by law [16]. Failure to pay wages is a direct violation of the rights of citizens, for which both administrative and criminal liability is provided.

Permission to make digital or hard copies of all or part of this work for personal or classroom use is granted without fee provided that copies are not made or distributed for profit or commercial advantage and that copies bear this notice and the full citation on the first page. Copyrights for components of this work owned by others than the author(s) must be honored. Abstracting with credit is permitted. To copy otherwise, or republish, to post on servers or to redistribute to lists, requires prior specific permission and/or a fee. Request permissions from Permissions@acm.org.

DEFIN2020, March 19-20, 2020, St.Petersburg, Russian Federation

(c) 2020 Copyright is held by the owner/author(s). Publication rights licensed to ACM.

ACM ISBN 978-1-4503-7530-6/20/03 ..\$15.00

https://doi.org/10.1145/3388984.3390624
In this paper labor remuneration offenses investigation methods and criminal penalties for wages and related social contributions crimes in the Russian Federation are considered

Since 1999 Art. 145.1. Of the Criminal Code of the Russian Federation "Non-payment of salaries, pensions, scholarships, allowances and other payments" has been introduced, according to which sanctions (up to imprisonment) for partial or full failure to pay these payments are to be imposed [17]. Sanctions of Art. 145.1 refer to employers who delay wages fully or partially for more than three months under condition that it has been proved they had the possibility of covering debts to employees, meaning, in economic terms, they had their own funds. Companies that did not have them are not covered by this article and are taken into account by Federal State Statistic Service as companies and organizations that have their salary arrears unpaid on time due to lack of their own funds or non-transferred money from the budget. So, on June 1, 2018, according to information provided by organizations (not related to small businesses), the total wage arrears in the range of observed economic activities amounted to 2817.8 million rubles [5].

\section{The State of the Art}

Judicial practice referring this article has already been established, and in general it boils down to the fact that the employer, having entered into an employment agreement (labor or civil law contract) and having actual opportunities to pay off payment arrears, did not do it. For example, the sentence of the magistrate of the judicial district No. 310 of the Rostokino district of Moscow in regard to part 2 of article 145.1 of the Criminal Code of the Russian Federation "Full failure to pay more than two months wages, pensions, scholarships, allowances and other statutory payments or payment of wages over two months below the federal minimum wage, committed out of mercenary or other personal interest by the head of the organization, by an individual employer, by the head of a branch, representative office or other body of a structural unit of the organization "[11]; sentence of June 5, 2017 in case No. 1-17 / 2017, judicial district No. 136 of the Dzerzhinsky District of Volgograd (Volgograd Region) [10], etc.

Investigation of such crimes is carried out in accordance with the methodological recommendations on the appointment of forensic economic examinations conducted in the framework of criminal cases initiated on the basis of the elements of crimes provided for by article 145.1 of the Criminal Code of the Russian Federation "Non-payment of wages, pensions, scholarships, 
allowances and other payments". According to these recommendations, under the forensic economic examination under the article in question is meant a study of the content of accounting records on charges, withholdings and salaries, pensions, scholarships, allowances and other payments to be paid [3].

However, in practice, this approach to the classification and detection of crimes in the sphere of wages does not fully reflect the real state of affairs. In modern reality entrepreneurs rarely directly resort to non-payment of wages. Today they come up with much more complicated schemes, for the investigation of which it is impossible to limit oneself only to the withdrawal and analysis of accounting documents. Accordingly, the methods of forensic economic examination should be constantly upgraded.

The most frequent cases of offenses related to non-payment of insurance premiums are the intentional reduction of the taxable basis for calculating social insurance premiums. Everyone knows that such results are achieved through the partial or full payment of wages "in the envelope". This is the main reason for the shortage of extra-budgetary funds. However the procedure for identifying and investigating such cases is extremely difficult.

Thus the criminal law characteristics of crimes in the sphere of remuneration are given in Art. 145.1 and 198, 199 of the Criminal Code of the Russian Federation. Accordingly, the methods of investigating such crimes and conducting economic forensic examinations are focused on the content of these articles. However, as mentioned above, the practice of modern crimes in the field of labor remuneration is much wider, and it is no longer possible to limit ourselves to such unambiguous and simple methods of classifying crimes and methods of their detection.

For a detailed analysis of these crimes, one must first refer to their criminological basis. The basic principle of forensic examinations should consist in their connection with the criminological component. Economic crimes in general and remuneration represent a very narrow and specific direction. The roots of such crimes are in the influence of economic factors, both external and internal, on the activities of economic entities.

\section{Case study}

Now let us take a closer look at the payment phenomena that are currently occurring in business as a response to new challenges and economic pressure. At the present moment it is extremely difficult to classify them as offenses of employers taking into account the current articles of the Criminal Code and methods of their investigation.

\subsection{The first case study}

Reducing the wages cost by transferring employees to part-time job, although the employee performs a much larger amount of work being busy all the day at work, and maybe even longer, nevertheless he is paid wages at the rate of a certain share, and the rest is given out "in an envelope". It is impossible not to agree that this type of offense is extremely difficult to establish and it is even harder to prove in court.
One cannot be limited to withdrawal and analysis of accounting documents only. This is just the case the documents will be correct, and the employer will be finally right. Although with such an action of the employer, at a minimum, social insurance premiums are lowered (not to mention the violation of the rights of the employee). Their underpayment is just a percentage of that part of wages, which is remunerated "in the envelope". In this case the following method can be proposed as a method of carrying out judicial economic examinations: a comparison of the actual amount of fulfilled work to labor standards per unit of time; obtaining information from colleagues or external partners who can confirm the time that the employee actually was present at a work place or performed labor functions.

One can also use data of an access system, fixing the arrival and departure of the employee. It is important to examine the records of the receipt of the necessary equipment or clothing as this records the time. For example in one company providing security unpaid overtime was proved only after analyzing the time of receipt and return of weapons. It is necessary to examine the number of meetings held by the employee, negotiated agreements with partners and other similar actions that will give unconditional evidence of the amount of work performed.

It is important to pay attention to such an assessment tool as labor standards. Judicial instances do not always resort to them during an investigation, while labor standards in sectoral tariff agreements exist or are established as recommended by industry. In any case they are reasonable indicators of how many units of products (services or any useful actions) a worker must perform for a certain period of time or how much time he must perform a particular job.

The offense to transfer the employee to part-time job while he performs full-time work can be classified under Art. 198, 199 of the Criminal Code of the Russian Federation [17], but the punishment is possible only for tax evasion of a large scale taking into account the total arrears amount of taxes, fees and insurance contributions to the Federal Tax Service.

\subsection{The second case study}

The employee is not officially employed, and the employer has delayed or failed to pay wages, or has not paid the due amount that was negotiated in advance. It should be noted that the initiation of proceedings under Art. 145.1 is possible only if the employer has entered into an employment agreement with a worker (civil law agreement) and for some reason did not pay him (or delayed payments for more than three months). However, in the modern Russian economy under the conditions of the informal labor market there are a numerous offenses in this respect, so that no labor agreements are negotiated in principle, although all labor relations attributes are evident. In the case of non-payment of wages or understating its size (as a result, non-accrual and nonpayment of social insurance premiums), all standard methods of investigation and forensic examinations fail.

First of all it is necessary to understand whether it is possible to see here an offense on the part of the employer: after all, if there is no labor agreement with the employee, then there is no 
payment either. However, labor relations can, if desired, be proved: the testimony of witnesses, video reports, documents, services rendered or products manufactured or work performed, etc.

According to the authors, non-execution of labor relations with an employee seriously violates the constitutional rights of the latter. Today a lot is said about the re-qualification of relations between an employee and an employer from civil law to labor law, if the performance of labor functions is systematic, the employee is subject to the requirements of labor regulations and working conditions of the organization. At the same time, the registration of civil law relations in the sphere of labor is a much smaller violation of the rights of workers, rather than their full legal nonexecution.

It seems to us crucial to introduce the criminal liability of the employer for violations of the fundamental rights of the employee. Art. 37 of the Constitution of the Russian Federation states: "Everyone has the right to work in conditions that meet safety and hygiene requirements, to remuneration for work without any discrimination and not lower than the minimum wage established by federal law, as well as the right to protection against unemployment" [1]. However, even the Constitution does not specify that every citizen should have the right to work within the framework of existing labor legislation and in accordance with it. Labor outside the scope of formal labor relations should be constitutionally prohibited, as well as forced labor.

In accordance with this, the authors insist the employer must be held criminally liable if the fact of the use of officially unformed employees is proved. However, today there is a legal opportunity to prove the existence of labor relationship between an employee and an employer and to prosecute him only for nonpayment of wages under article 145.1 of the Criminal Code of the Russian Federation forgetting about the violation of the citizen rights under such conditions. Informal labor activity may have other negative impact on an employee, for example, injuries or illnesses resulting from unformed labor are not regulated by law.

The very fact of the proliferation of the illegal labor market and the social insecurity of such workers is noted by some foreign scientists. For example, Johanna Wallisto, an expert at the Development Monitoring Center in Estonia, believes that the organization of labor has changed so much over the past decades that it is becoming more and more difficult to define subordination and related labor relations. "Those who work on the basis of an employment contract are most protected: their protection derives from labor relations and social insurance. For other types of labor relations, such protection is currently absent. From the point of view of Estonian labor law, many people are not employed, for example, on the basis of a contract of obligation or via platforms. At the same time, they also need protection and social guarantees if the appropriate type of work becomes their main type of work "[9]. Thus, work in such conditions is not regulated by the rules of law and, of course, it contradicts the fundamental rights of a citizen in a social state, which must be fixed, first of all, by the constitution.

\subsection{The third case study}

The third situation demonstrates a more complicated, even knowledge-intensive method. Employers can use a completely legitimate way for costs optimization, namely rationing labor, that is setting standards for time, production, maintenance, etc. According to Art. 159 of the Labor Code of the Russian Federation, it is the right of the employer, and according to the same article the employer independently organizes the rationing of labor at a commercial enterprise [16]. Thus, the new calculated labor standards will be such that, for objective reasons, some of the workers are transferred to part-time job, with a corresponding proportional reduction in wages, which in this case is not needed to be covered by extra cash. Actually the majority of workers will fail to complete their work within working hours (since the labor standards are exceeded) and thus will be forced to work overtime.

Today labor standards are measured by very subjective methods that are not strictly regulated. And the experimentalstatic method of labor valuation is generally calculated on the basis of the knowledge of the rate-setter himself and previously established standards, or the definition of standards is based on data obtained from equipment technical certificates, from other enterprises, considering typical labor standards in the industry, etc. It is extremely difficult to investigate such offenses. After all, in order to evaluate the regulations on the labor rationing the forensic expert must possess serious background in labor economics.

\subsection{The fourth case study}

The employer does not pay wages for the reasons mentioned at the beginning: due to the lack of his own funds. At the same time, it is not a secret to anyone that many organizations, before declaring themselves bankrupt or ceasing to pay wages, withdraw assets from the organization, or at least liquid assets.

In addition, some of them start-up a new firm (and not just one) into which accounts counterparties funds can be transferred. Then, formally, according to the documents, the "bankrupt" company has no its own funds, and it can formally escape responsibility. In order to perform a forensic economic examination it is necessary to track all the transactions of a "bankrupt" company and to carry out thorough analysis, to examine its counterparties as well. It is necessary to find out whether there has been a sudden funds increase in accounts of counterparties, especially if their managers are affiliates with respect to the company under study.

\section{Discussion}

Great attention should be paid to the analysis of the structure and amount of debts receivable, and if it has increased, then it is necessary to find out the reasons for this. Of course, in the course of such an investigation, other offenses from the category of economic crimes may also come to light. However, when investigating economic crimes and carrying out a forensic economic examination, the mail principle should be the integrity and indivisibility of the organization's economic activities. And 
the main methods of judicial economic expertise are analysis and synthesis. The analysis presumes the division of economic activity into elements and the study of each of them separately. Whereas synthesis is the accumulation of all the parts into a single whole and the definition of a general concept or logic of the activity of the organization as a whole, on the basis of which one can understand the criminological basis of the crime, and then its scheme.

The letter of the Federal Tax Service of Russia dated July 13, 2017 No. ED-4-2 / 13650 "On the direction of guidelines for establishing circumstances during tax and procedural inspections that indicate intent in the actions of taxpayer officials, aimed at the non-payment of taxes (fees)" [6] (together with the "Methodical recommendations "On the study and proof of the facts of deliberate non-payment or incomplete payment of the tax (fee)", approved by the Russian IC, FTS of Russia [2]) can be used as a tool for performing judicial economic examinations. This document sets out in details many business schemes for the purpose of tax evasion. However, a similar document should be developed outlining current illegal business schemes that allow an employer to commit wages offenses.

\section{Conclusion}

In conclusion it should be noted that establishing such responsibility, including criminal liability, for offenses in the area of intended reducing the taxable base for social insurance premiums, the government, of course, aims to withdraw the labor market from the informal sector and to increase the extrabudgetary funds surplus. However, in practice, competitors and detractors of the company get an effective competition tool. And one more additional problem arises for business.

According to the authors, proposals in the field of tightening or any change in punishment for economic crimes should be based on a criminological study of its causes, incentives and consequences. The criminalistic component of any offense or crime is based on its criminological basis, so the punishment should logically follow from the cause, so as not to give rise to abuses and various perverted forms of its use, especially when it comes to economic crimes.

Nevertheless it seems highly unlikely that tougher penalties for concealing the taxable base for social insurance premiums will lead to the expected significant increase in extrabudgetary funds. Thus, in this paper typical labor remuneration offenses are revealed, methods for investigating these offenses are formulated, legislation amendments to prevent unfair practices are proposed.

\section{ACKNOWLEDGMENT}

The authors express their special gratitude to Krasnoyarsk Regional Center for Career Guidance and Qualifications Development and personally to the Director Zulfiya Alekseevna Ismagilova, as well as to the Representative Office of the National Agency for Qualifications Development in Krasnoyarsk, to the Agency for Labor and Employment of the Krasnoyarsk Territory and personally to Viktor Vasilievich Novikov for their cooperation and participation and in the survey who supported this work and helped the authors to get results of better quality.

\section{REFERENCES}

[1] The Constitution of the Russian Federation.Adopted by vote on 12.12.1993.As amended by the Laws of the Russian Federation on amendments to the Constitution of the Russian Federation. No. 6-FKZ, of 30.12.2008. No. 7-FKZ, of 30.12.2008. No. 2-FKZ, of 05.02.2014. 11-FKZ of 21.07.2014.

[2] On the study and proof of the facts of intentional non-payment or incomplete payment of the tax (fee). Methodical recommendations.Approved. SK Russia, the Federal Tax Service of Russia[Electronicsource]. Availableat: http://www.consultant.ru/document/cons_doc_LAW_220597/96c60c11ee5b738 82df84a7de3c4fb18f1a01961/.Dateofreference: 23.10 .2018

[3] Non-payment of wages, pensions, scholarships, allowances and other payments Methodical recommendations on the appointment of forensic economic examinations conducted in the framework of criminal cases initiated on the basis of the elements of the crimes provided for by article 1451 of the Criminal Code of the Russian Federation [Electronicsource] Availableat:http://webcache.googleusercontent.com/search?q=cache:h61pXfuI WvAJ:altai.sledcom.ru/upload/site40/images_in_parse_content/expert_1451. $\mathrm{doc}+\& \mathrm{~cd}=1 \& \mathrm{hl}=\mathrm{ru} \& \mathrm{ct}=\mathrm{clnk} \& \mathrm{gl}=\mathrm{ru} \& \mathrm{ctl} \mathrm{cl}=\mathrm{ru} \&$ ctlcl\&\&cl.html. Dateofreference:25.10.2018.

[4] Tax Code of the Russian Federation. Part one. 1998. No. 146-FZ (as amended on 27.12.2018)[Electronicsource] Availableat:http://www.consultant.ru/document/cons_doc_LAW_19671/.Dateo freference:20.10.2018.

[5] The official site of the Federal State Statistic Service [Electronicsource] Availableat:http://gks.ru.Dateofreference:17.10.2018.

[6] On sending methodological recommendations for establishing circumstances during tax and procedural inspections indicating intention in the actions of taxpayer officials aimed at non-payment of taxes (fees). Letter of the Federal Tax Service of Russia ED-4-2/13650.Dated 13July, 2017 [Electronicsource] Availableat:http://www.consultant.ru/document/ cons_doc_LAW_220597/96c60c11ee5b73882df84a7de3c4fb18f1a01961/.Date ofreference: 23.10 .2018 .

[7] On the case of verifying the constitutionality of the provisions of Article 129 , Parts One and Three of Article 133, Parts One, Two, Third, Fourth and Eleventh Article 133.1 of the Labor Code of the Russian Federation in connection with the complaints of citizens V. S. Grigorieva, O. L. Dadey, N.A Kapurina and I.Ya. Kurash. Resolution of the Constitutional Court of the Russian Federation of 2017. 38-P [Electronicsource] Availableat:http://www.consultant.ru/document/cons_doc_LAW_11916/a5973 0c21f468e7170ae8a178229db5ee6d862e0/.Dateofreference:23.10.2018.

[8] On the peculiarities of the application of professional standards in terms of the requirements mandatory for the use of state extra-budgetary funds of the Russian Federation, state or municipal institutions, state or municipal unitary enterprises, as well as state corporations, business companies, more than fifty percent of shares (shares) in the authorized capital of which is in the state ownership or municipal property. Government Decree of 27 June, 2016. 584

[9] The legal status of an employee requires a broader understanding [Electronicsource]. Availableat:https://www.riigikogu.ee/en/tsentr-monitoringarazvitiya/pravovoj-status-rabotnika-trebuet-bolee-shirokogo-osmysleniya/. Dateofreference: 17.10 .2018

[10] The verdict of 5June, 2017 in case 1-17/2017, judicial district 136 of the Dzerzhinsky district of Volgograd. Volgograd region[Electronicsource] Availableat:http://sudact.ru/magistrate/doc/On2GA23h2KQn/.Dateofreference: 16.10.2018.

[11] Full non-payment of wages, pensions, scholarships, allowances and other statutory payments or wages of more than two months over two months at a rate below the minimum wage established by federal law, committed out of mercenary or other personal interest by the head of the organization, the employer - an individual, the head of a branch, representative office, or other isolated structural divisions of the organization. The verdict of the magistrate of the judicial district 310 of the Rostokino district of Moscow as regards part 2 of article 145.1 of the Criminal Code of the Russian Federation [Electronicsource] Availableat:https://advokat15ak.ru/.Dateofreference:13.10.2018.

[12] Coercion to contribute[Electronicsource]. Availableat:https://www.rbc.ru/newspaper/2017/04/12/58ecd23c9a7947984c02 91a0.Dateofreference: 17.10.2018.

[13] E. N. Sochneva. 2018. Analysis of the consequences of increasing the minimum wage in Russia for the regional economy (on the example of the Krasnoyarsk Territory). Labor and social relations. 2018, 4, 13-25.

[14] The statistics of criminal cases against business has stabilized.Economy and life. 2017.No. 08 (9674) [Electronicsource]. Availableat:https://www.egonline.ru/article/338249/. Dateofreference: 17.10.2018.

[15] Shadow employment is growing again. Labor market monitoring [Electronicsource]. 
Availableat:https://www.kommersant.ru/doc/3391605.Dateofreference:17.10.20 18.

[16] The Labor Code of the Russian Federation of 30December, 2001. 197-FZ (as amended on 27December, 2018)[Electronicsource]. Availableat: http://www.consultant.ru/document/cons_doc_LAW_34683/.Dateofreference:2 0.10 .2018 .

[17] Criminal Code of the Russian Federation dated 13.06.1996. 63-FZ (as amended on 27.12.2018) [Electronicsource]. Availableat:http://www.consultant.ru/document/cons_doc_LAW_10699/ Dateofreference:12.01.2019.

[18] On Amendments to the Criminal Code of the Russian Federation and the Criminal Procedure Code of the Russian Federation in connection with the improvement of the legal regulation of relations connected with the payment of insurance premiums to state extra-budgetary funds.Federal Law.Dated 29July, 2017.250[Electronicsource].

Availableat:http://www.consultant.ru/document/cons_doc_LAW_221216/.Date ofreference:20.10.2018.

[19] On Amendments to Certain Legislative Acts of the Russian Federation regarding the increase in the minimum wage to the subsistence minimum of the working population. Federal Law of 28.12.2017, 421 [Electronicsource]. Availableat:http://www.consultant.ru/document/cons_doc_LAW_286456/.Date ofreference:21.10.2018.

[20] Arrigo Opocher and Ian Steedman. 2009. Input and Output Numeraire. Cambridge Journal of Economics, 2009,33(5), 937-948.

[21] Gary Fields. 1994. The Unemployment Effects of Minimum Wages.International Journal of Manpower, 1994, 15(2), 74-81.

[22] Robert L. Vienneau. On Labor Demand and Equilibria of the Firm.Manchester School. September, 2005, Vol. 73, 5, 612-619. 